\title{
Bandung's Image as a Tourist Destination: An Application of Quantitative and Qualitative Approach
}

\author{
Agustinus Februadi $^{\mathrm{a}^{*}}$, Nono Wibisono ${ }^{\mathrm{b}}$, and Dewi Purnamasari ${ }^{\mathrm{c}}$ \\ ${ }^{\mathrm{a}, \mathrm{b}}$ Associate Professor, Departement of Business Administration, Politeknik Negeri Bandung, \\ Indonesia \\ ${ }^{\mathrm{c}}$ Graduate, Departement of Business Administration, Politeknik Negeri Bandung, Indonesia
}

Received 11 November 2018; accepted 10 January 2019

\begin{abstract}
Bandung is a popular tourist destination in Indonesia and a gateway for tourists who visit destinations around greater Bandung areas. Currently, Bandung is also known as a culinary, shopping, and nature tourism destination. Past studies have measured the image of Bandung as a tourist destination. However, the measurements were done partially due to the use of quantitative method only. Thus, the results were not comprehensive. To resolve the drawbacks of the previous studies, this study used both qualitative and quantitative approaches. Data were collected from 430 domestic tourists by ways of structured and unstructured interviews in 20 different destinations in Bandung and the surrounding. Data were processed by descriptive statistical methods, factor analysis and content analysis. The results of quantitative analysis show that, in term of functional-attribute, Bandung was positively perceived as a destination characterized with natural scenic beauty, many interesting places, and various exotic foods. In terms of the psychological-attribute, Bandung was perceived as the right place for shopping and culinary tourism. The results of qualitative analysis indicate that, functionally, Bandung was a destination with natural scenic beauty, pleasant weather and provide various exotic foods. Psychologically, the tourists experienced calm and tranquil atmosphere, happiness, and comfort.
\end{abstract}

\section{INTRODUCTION}

Bandung is one of popular tourist destinations in Indonesia that attracts domestic and foreign tourists. Tourists come to Bandung to visit tourist attractions in the city and various natural scenic tourist attractions around the greater Bandung area. Thus, Bandung is known as the entrance gate to tourists who want to visit tourist destinations located in Bandung Regency and West Bandung Regency (Mardiana, 2018).

In term of resources, Bandung is like Singapore, has no natural and energy resources (Salim, 2014). Resources retained by the city of Bandung are human resources. Therefore, the economic development of Bandung is based on human resources such as a creative economy. Culinary, fashion 
and design are creative economy based businesses that grow steadily in Bandung (Salim, 2014). In 2015, the government has launched a program that set Bandung as a culinary tourism destination in addition to the already established image of Bandung as a shopping destination (Widianto, 2015). As a result, Bandung has a variety of images as a tourist destination including shopping destinations, culinary tourism, nature tourism, and other images that are in accordance with the tourist interests and experiences (Efendi, 2017; Mardiana, 2018; Widianto, 2015).

A number of research on the image of Bandung as a tourist destination has been carried out (Agustiani, 2017; Khoiriana \& Nurlambang, 2017; Suciani, 2014), but all of these studies used a quantitative approach where the images were measured based on pre-determined destination attributes resulting in partial measurements. More than two decades ago, Echtner and Richie (1991) proposed the measurement of a tourist destination image should be based on attributes (quantitative) and holistic (qualitative) measurements. A holistic impression is a psychological or emotional impression that is represented by one or two words that describe the destination as a whole (Echtner \& Ritchie, 1991). Measurement of destination image based on just one aspect will result in incomplete and inaccurate measurements. Basically, tourism activities do not only involve tangible-functional attributes of the destination, but also involve things that are intangible-psychological (Echtner \& Ritchie, 1991). As a result, tourists will develop a destination image based on the impression of the functional attributes and psychological-holistic impression of the destination they visited (Echtner \& Ritchie, 1991).

Considering that the previous measurements of Bandung image as a tourist destination were incomplete due to the use of quantitative approach only, this study focuses on measuring the image of Bandung using a mixed method where both quantitative and qualitative approaches are used. This is important in order to capture and identify tourist's impressions of Bandung thoroughly. The comprehensive image of Bandung, as a result, then can be used as a basis for policy making by the destination marketing organisation of Bandung city in improving the tourism sector of Bandung.

\section{LITERATURE REVIEW}

\section{Destination Image}

In the context of tourism marketing, destination images have often been investigated, from the formation process, the forming factors, as well as the consequences of destination images have been widely reviewed and examined. Scholars argue that destination images are best studied by involving two aspects, namely affective and cognitive aspects (Beerli \& Martin, 2004; Sönmez \& Sirakaya, 2002). The destination image model created by Baloglu and McCleary (1999a) consisting of cognitive imagery and affective imagery seems to be the most accepted and most cited model (Chew \& Jahari, 2014). Cognitive imagery refers to beliefs and knowledge of the attributes of a tourist destination. Whereas affective images refer to emotions or feelings inherent in a tourist destination. A study conducted by Pike (2002) shows that cognitive images that focus on tangible attributes were studied most frequently, while affective images are slightly overlooked with only six studies over 30 years of observation.

Previous destination image studies are more focused on identifying the forming factors or the factors that affecting the image of the destination. For example, psychological motivation is shown to have a significant effect on the cognitive and affective components of the destination image (Baloglu, 200o; Baloglu \& McCleary, 1999a; San Martin \& Rodríguez del Bosque, 2008). In 
contrast, Li et al. (2010) found that the travel motivation variable had a significant effect on cognitive image, while the affective image was only significantly affected by the escape variable. Other variables that have been shown to influence cognitive images and affective images significantly include, previous travel experiences (Baloglu, 2000; Beerli \& Martin, 2004), stimulus factors, length of stay (Fakeye \& Crompton, 1991) and the sum of information and advertisement obtained (Baloglu, 200o; Baloglu \& McCleary, 1999a).

Regarding the consequences of destination images, previous research shows that destination images have a significant effect on prior behaviour (Baloglu, 2000) and after visits (Court \& Lupton, 1997; Prayag, 2009). The results of a number of studies found that cognitive images and affective images affect overall image, intention to visit, and intention to recommend (Baloglu \& McCleary, 1999b; Qu, Kim, \& Im, 2011; Wang \& Hsu, 2010). But Li et al. (2010) found that revisit intention was only affected by affective images. Previous research also found empirical evidence about the influence of destination images on satisfaction (Assaker, Vinzi, \& O'Connor, 2011; Prayag, 2009) and perceived quality (Lee, Lee, \& Lee, 2005).

Thus, it can be said that having a positive destination image is very important for a tourist destination because it will also have a positive impact on tourist visits. Therefore, the image of the destination needs to be measured so that the actual image can be identified and the stakeholders can provide the right response for the improvement of the destination.

\section{Measurement of Destination Image}

The images of a destination can be measured using two approaches, namely: the structured (quantitative) and the unstructured (qualitative) approaches (Baloglu \& Love, 2005; Echtner \& Ritchie, 1991). The structured approach requires the respondents to respond, mainly, in the form of semantic differential and Likert scales for questions that are divided into cognitive and affective dimensions (Baloglu \& Mangaloglu, 2001; Dolnicar \& Grün, 2013). The unstructured approach allows the respondents to freely express their emotional impressions toward the destination. Previous studies show that structured approach was used far more frequently because of its ease in analysing data (Pan \& Li, 2011; Selby \& Morgan, 1996). This was supported by Pike (2002) when reviewing image study articles from 1973 to 2000 found that 114 out of 142 (80\%) articles used structured approach. Likewise, when reviewing 86 articles published in the best tourism journals between 2002 and 2012, Dolnicar and Grun (2013) found 75\% of the articles using a structured approach.

One disadvantage of a structured approach is the possibility of bias from researchers when determining the destination attributes to be measured (Svetlana Stepchenkova \& Li, 2014). The structured approach also gives respondents no opportunity to express their opinions beyond of what is asked in the questionnaire. This resulted in difficulties in identifying the real reasons they came to the destination (Echtner \& Ritchie, 1991; Pan \& Li, 2011). An unstructured approach seems to solve this problem. The unstructured method most often used to measure destination images is likely to be the three open questions proposed by Echtner \& Ritchie (1991) (X. Li \& Stepchenkova, 2012; Tasci, Gartner, \& Tamer Cavusgil, 2007).

Based on a review of literature on destination image from 1975 to 1990, Echtner and Ritchie (1991) argue that destination image has two components, namely components based on attributes and holistic components. Each component has functional (tangible) and psychological (intangible) characteristics. Destination images can also range from the unique to the common. Components based on attributes are ranged from functional (tangible) such as shops, parks, roads to those that 
are psychological (intangible) such as local residents hospitality, service quality and so on. These attributes can also represent something that is general (found in each destination) to a unique one (only found in one destination).

The holistic component is measured by two open questions (Echtner \& Ritchie, 1991, p. 11):

1. "What images or characteristics come to mind when you think of....as a travel destination?, and

2. "How would you describe the atmosphere or mood that you would expect to experience while visiting......?"

The first question is functional, while the second is psychological. The response to the second question is an affective assessment, such as exciting, boring, relaxed and so on. Thus the second question resembles the affective component proposed by Baloglu and Brinberg (1997). Furthermore, the holistic component refers to the mental picture or general image of a destination that resembles the overall impression of the destination image. This holistic component is important as it indicates how a destination is portrayed in the consumers' mind, as well as what images are associated with a destination (S. Stepchenkova \& Morrison, 2008). The uniqueness of a destination are measured by the third question:

3. "Please list any distinctive or unique tourist that you can think of......"

This unique component is to distinguish a destination from other destinations. Thus, the unstructured method proposed by Echtner and Ritchie seems to be in line with the overall image of the cognitive-affective-image concept, which is also in line with MacKay and Fessenmaier's (1997, p. 538) statement that "A destination image is a composite of various products (attractions) and attributes of woven into a total impression".

\section{RESEARCH METHOD}

This research adopts a mixed method used by Choi et al. (1999) and Hui and Wan (2003) which combined the quantitative and qualitative approaches. The quantitative approach aims to understand the factors that represent the image dimensions of Bandung as a tourist destination based on destination attributes that are commonly used in previous research. The qualitative approach aims to provide respondents with the opportunity to freely express their impressions of Bandung as a tourist destination.

The implementation of this research was carried out in three stages:

\section{First Stage: Designing Research Instrument}

The research instrument used consists of three parts. The first part of this instrument contains three questions about the respondent's demographic background, including: gender, age, and city of origin. The second part contained 24 statements that measure functional and psychological attributes. These statements were taken from previous studies (Choi et al., 1999; Echtner \& Ritchie, 1991; Hui \& Wan, 2003) and adapted to the conditions and situations of Bandung. Respondents were asked if they agree with the 24 statements using a five-point scale ranging from 1 (strongly disagree) to 5 (strongly agree). The third part of this instrument comprised three open questions adopted from Echtner and Ritchie (1991). This third part is the qualitative aspects of this research. The three questions are as follows: 
1. What images or characteristics cross your mind when you think of Bandung as a tourist destination?

2. What kind of atmosphere or mood do you expect to experience when visiting Bandung?

3. Mention the distinctive or unique tourist attractions in Bandung.

\section{The Second Stage: Data Collection}

Data were collected by means of direct interviews with respondents. The sample of respondents interviewed was 430 domestic tourists from regions other than Bandung, who stayed at least one night in Bandung or greater Bandung areas. The interviews were carried out at 20 tourist attraction sites in Bandung and the greater Bandung areas.

\section{The Third Stage: Data Processing}

Data from the second part of the questionnaire were processed using factor analysis method. The purpose of factor analysis is to classify the statements in the questionnaire into several factors that can be considered as dimensions of the image of Bandung. The internal consistency of each factor were evaluated using the Cronbach alpha test. The factors extracted were then labelled based on the item statements that are grouped in these factors. The mean score of each item statements were also identified. Item statements with a high mean score were considered as the main attribute. A high mean score shows a positive image for Bandung.

Qualitative data from the third part were processed based on the frequency of occurrence. The data together with the main attribute data were then entered into a table that described three continuum measurements of destination image (1, Attribute-Holistic; 2, Unique-Common; 3, Functional-Psychological) as applied by Choi et al. (1999) and Hui and Wan (2003).

Table 1. The Three Continuum format

\begin{tabular}{ccccc}
\hline & Functional & Mean/\% & Psychological & Mean $/ \%$ \\
\hline Attribute-Holistic & & & & \\
Attribute & $\ldots$ & Mean & $\ldots$. & Mean \\
& $\ldots$. & Mean & $\ldots$. & Mean \\
& $\ldots$ & Mean & $\ldots$. & Mean \\
Holistic & & & & \\
& $\ldots$ & $\ldots \%$ & $\ldots$. & $\ldots \%$ \\
Unique-Common & $\ldots$ & $\ldots \%$ & $\ldots$. & $\ldots \%$ \\
Unique & $\ldots$ & $\ldots \%$ & $\ldots$. & $\ldots \%$ \\
& $\ldots$ & $\ldots \%$ & & \\
& $\ldots$. & $\ldots \%$ & $\ldots$. & $\ldots \%$ \\
& $\ldots$. & $\ldots \%$ & $\ldots$. & $\ldots \%$ \\
Common & $\ldots$ & $\ldots \%$ & $\ldots$. & $\ldots \%$ \\
& $\ldots$. & $\ldots \%$ & $\ldots$. & $\ldots \%$ \\
& $\ldots$. & $\ldots \%$ & $\ldots$. & $\ldots \%$ \\
\hline
\end{tabular}


Once the above table is filled, the image of Bandung as a tourist destination can be identified comprehensively in accordance with the concept of measuring the destination image proposed by Echtner and Ritchie (1991).

\section{RESULT}

\section{Profile of Respondent}

The data for this study were taken from interviews conducted at 20 tourist destination locations scattered in the city of Bandung and surrounding areas as shown in Table 2 below.

Table 2. Data Collection locations

\begin{tabular}{|c|c|c|}
\hline No & Location & $\begin{array}{l}\text { No. of } \\
\text { Respondents }\end{array}$ \\
\hline 1 & Kawah Putih & 21 \\
\hline 2 & Glamping Lakeside & 22 \\
\hline 3 & Cimanggu & 20 \\
\hline 4 & Rancaupas & 24 \\
\hline 5 & Ciwalini & 23 \\
\hline 6 & Rancabali Plantation & 24 \\
\hline 7 & The Lodge, Lembang & 20 \\
\hline 8 & The Ranch, Lembang & 20 \\
\hline 9 & Floating Market, Lembang & 20 \\
\hline 10 & Orchid Forest, Cikole & 20 \\
\hline 11 & Tangkuban Perahu Mountain & 22 \\
\hline 12 & Djuanda National Park & 20 \\
\hline 13 & Geology Museum & 20 \\
\hline 14 & Factory Outlet around Dago & 23 \\
\hline 15 & Pasar Baru & 22 \\
\hline 16 & China Town & 20 \\
\hline 17 & Alun-alun/Gedung Merdeka & 20 \\
\hline 18 & Cibaduyut & 24 \\
\hline 19 & Trans Studio Mall & 24 \\
\hline \multirow[t]{2}{*}{20} & Cihampelas Walk & 21 \\
\hline & Total respondents & 430 \\
\hline
\end{tabular}

The respondents of this study are 430 domestic tourists coming from regions other than Bandung. The respondents' profile summary is presented in Table 3 below. Of the 430 respondents, 198 people or $46 \%$ were male and 232 people or $54 \%$ were female. The majority of these respondents came from the 20-29 age group. Most of the respondents came from the cities in West Java.

\section{Factor Analysis Results}

The purpose of conducting a factor analysis on the 24 measurement statements in the questionnaire was to group these statements into fewer factors which represent the image dimension of Bandung as a tourist destination. 
In conducting factor analysis this study uses criteria greater and equal to 0.4 for factor loading which is considered significant (Hair, Black, Babin, \& Anderson, 2010). From this analysis two statements, namely the statement "Information for tourists is easily obtained in Bandung" and the statement "Bandung provides a variety of cafes to hang out" were removed from subsequent analysis because both statements had factor loadings less than 0.4 .

Table 3. Profile of respondents

\begin{tabular}{lrr}
\hline Frequency & \multicolumn{2}{c}{ Percentage } \\
\hline Gender & 198 & 46 \\
Male & 232 & 54 \\
Female & & \\
Age & 82 & 19.1 \\
$<20$ & 194 & 45.1 \\
$20-29$ & 67 & 15.6 \\
$30-39$ & 46 & 10.7 \\
$40-49$ & 35 & 8.1 \\
$50-59$ & 6 & 1.4 \\
$>59$ & & \\
Province of origin & 199 & 46.3 \\
West Java & 68 & 15.8 \\
Jakarta & 33 & $7 \cdot 7$ \\
Central Java & 24 & 5.6 \\
Banten & 23 & $5 \cdot 3$ \\
East Java & 14 & $3 \cdot 3$ \\
Riau & 12 & 2.8 \\
Yogyakarta & 57 & 13.2 \\
Others & &
\end{tabular}

The factor analysis extracted six factors. Factor 1 comprised of four statements relating to nature and comfort. The statements are "Lots of natural scenic beauty"; "Many interesting places"; "Restful and relaxing places"; and the statement "Pleasant weather". The second factor comprised of four statements relating to culinary including "Food is varied"; "The right place for culinary tourism"; "Provides various exotic foods", and "Provides various food souvenirs". The third factor included four statements relating to shopping for products at a number of factory outlets in Bandung. The statements are: "Many factory outlets"; "The right place for shopping"; "Good place for shopping"; and "Good quality products". The fourth factor included statements about facilities available for tourists such as: "Many gardens and parks"; "Good quality restaurants and hotels"; and "Good services and facilities for tourists". The hospitality of Bandung residents is shown by the fifth factor. This factor comprised of four statements including "Local people are friendly"; "Local people are courteous"; "Local people provide good service to tourists"; and "Local people are honest".

The last factor is the factor that shows traffic in Bandung in relation to access to tourist destinations. This factor encompassed of three statements such as "Safe place to visit"; "Easy access to tourist attractions"; and "Traffic supports the convenience of traveling".

After all statements were grouped into six factors, the next step was to measure the internal consistency of each statement in each factor. This reliability test was done using the Cronbach alpha test. All the Cronbach alpha scores were greater than 0.5 indicating high correlation between the statements. For more details, see Table 4 below. 
Table 4. Factor analysis of image items

\begin{tabular}{|c|c|c|c|c|}
\hline Factor and Indicator & Mean & Loading & Alpha & Eigenvalue \\
\hline Factor 1: Nature and comfort & 4.280 & & 0.703 & 6.566 \\
\hline Lots of natural scenic beauty & 4.412 & 0.649 & & \\
\hline Many interesting places & $4 \cdot 393$ & 0.763 & & \\
\hline Restful and relaxing places & 4.260 & 0.713 & & \\
\hline Pleasant Weather & $4 \cdot 506$ & 0.590 & & \\
\hline Factor 2: Culinary tourism & 4.227 & & 0.803 & 2.018 \\
\hline Food is varied & $4 \cdot 323$ & 0.773 & & \\
\hline The right place for culinary tourism & 4.219 & 0.732 & & \\
\hline Provide various exotic foods & 4.184 & 0.751 & & \\
\hline Provide various food souvenir & 4.181 & 0.707 & & \\
\hline Factor 3: Shopping tourism & 4.107 & & 0.765 & 1.582 \\
\hline Many factory outlets & 4.228 & 0.741 & & \\
\hline The right place for shopping & 4.221 & 0.743 & & \\
\hline Good place for shopping & 4.021 & 0.750 & & \\
\hline Good quality products & 3.958 & 0.666 & & \\
\hline Factor 4: Tourism facilities & 4.000 & & 0.675 & 1.488 \\
\hline Many gardens and parks & 4.058 & 0.551 & & \\
\hline Good quality hotel and restaurant & 4.000 & 0.807 & & \\
\hline Good service and facilities for tourist & 3.942 & 0.648 & & \\
\hline Factor 5: Local people hospitality & 3.916 & & 0.848 & 1.081 \\
\hline Local people are friendly & 4.081 & 0.833 & & \\
\hline Local people are courteous & 4.058 & 0.895 & & \\
\hline Local people provide good service to tourists & 3.833 & 0.518 & & \\
\hline Local people are honest & 3.693 & 0.770 & & \\
\hline Factor 6: Traffic & 3.465 & & 0.596 & 1.025 \\
\hline Safe place to visit & 3.872 & 0.666 & & \\
\hline Easy access to tourist attractions & $3 \cdot 382$ & 0.638 & & \\
\hline Traffic supports convenience of traveling & 3.142 & 0.711 & & \\
\hline
\end{tabular}

\section{The Three Continuums of Destination Image}

The results of the quantitative and qualitative analysis were presented using the three continuum of destination image format. Three statements with the highest mean score included in the functional-attribute category are 'Lots of natural scenic beauty' $(4,41)$, 'Many interesting places' $(4,39)$, and 'Food is varied' (4.32). Whereas for psychological attribute statements are: 'The right place for shopping' (4.22), 'The right place for culinary tourism' (4.22), and 'Local people are friendly' (4.08). All of these mean scores are greater than 4.00 demonstrating a positive image for Bandung.

The second line shows the functional-psychological holistic image components. This line shows that many respondents think that Bandung was a tourist destination with a pleasant weather, has natural scenic beauty, and has good exotic food. Tourists visited Bandung also experienced a calm and tranquil atmosphere, and happy with their trip. 
Table 5. The Three Continuums of Destination Image

\begin{tabular}{|c|c|c|c|c|}
\hline & Functional & Mean $/ \%$ & Psychological & Mean/\% \\
\hline \multicolumn{5}{|c|}{ Attribute - Holistic } \\
\hline \multirow[t]{3}{*}{ Attribute } & $\begin{array}{l}\text { Lots of natural scenic } \\
\text { beauty }\end{array}$ & $4 \cdot 41$ & $\begin{array}{l}\text { The right place for } \\
\text { shopping }\end{array}$ & 4.22 \\
\hline & Many interesting place & $4 \cdot 39$ & $\begin{array}{l}\text { The right place for } \\
\text { culinary tourism }\end{array}$ & 4.22 \\
\hline & Food is varied & $4 \cdot 32$ & Local people are friendly & 4.08 \\
\hline \multirow[t]{2}{*}{ Holistic } & Pleasant weather & 22.1 & Calm and tranquil & $54 \cdot 4$ \\
\hline & Natural scenic beauty & $13 \cdot 4$ & Happy & 40.2 \\
\hline \multicolumn{5}{|c|}{ Unique - Common } \\
\hline \multirow[t]{3}{*}{ Unique } & Tangkuban Perahu & 14.0 & Calm and tranquil & $54 \cdot 4$ \\
\hline & Lembang & 12.4 & Happy & 40.2 \\
\hline & Kawah Putih & 9.5 & Comfy & 19.4 \\
\hline \multirow[t]{3}{*}{ Common } & Pleasant weather & 22.1 & Local people are friendly & 3.8 \\
\hline & Natural scenic beauty & $13 \cdot 4$ & Holiday & 3.1 \\
\hline & Good exotic food & 6.9 & & \\
\hline
\end{tabular}

The functional-psychological of the unique components are displayed on the third line. Tangkuban Perahu, Lembang, and Kawah Putih were the attractions that tourist remember most when they think of Bandung as a tourist destination. In addition, tourist were enjoy their visit in Bandung since most of them regarded local people in Bandung were friendly.

\section{DISCUSSION}

The results of this study show that Bandung has a positive image as a tourist destination. From the quantitative approach, the results show that Bandung is seen as the right city for culinary tourism, shopping tourism, and nature tourism. This is consistent with the results of previous studies on the image of Bandung (Agustiani, 2017; Khoiriana \& Nurlambang, 2017; Suciani, 2014). The results of the qualitative approach highlighted the mood or atmosphere experienced by the tourists in Bandung. The atmosphere of calm, tranquil, and comfy as expressed by the tourists have never been identified before. This study is the first attempt to identify these emotional impressions toward Bandung.

With regard to the research method used, this study confirmed that the use of quantitative and qualitative combination approaches resulted in a more comprehensive image of a destination (Choi et al., 1999; Echtner \& Ritchie, 1991; Hui \& Wan, 2003). The results of this study note that in assessing the image of a destination, the quantitative and qualitative approaches should be employed. This is important as the application of the combination approaches provide the respondents opportunities to freely express their emotional impression toward the destination, something that cannot be offered by the quantitative approach alone. 


\section{CONCLUSION AND IMPLICATIONS}

By using the combination of quantitative and qualitative approaches, the comprehensive image of Bandung was extracted. Overall, Bandung was positively perceived as a destination with natural scenic beauty, many interesting places with various exotic foods. Bandung was also perceived as a good place for shopping and culinary tourism. Psychologically, tourists experienced a calm and tranquil atmosphere while visiting Bandung. Moreover, Tangkuban Perahu, Lembang, and Kawah Putih were identified as the distinctive tourist attractions in Bandung.

The implications conveyed by the results of this study are: the statements identified in the functional attribute components can help the destination marketing organization to understand the competitive position of Bandung as a tourist destination. Whereas, the psychological attribute components show statements that strengthens Bandung's image as a culinary and shopping destination. With many cafes, restaurants, street foods and factory outlets that scattered throughout the city of Bandung, a clear differentiation strategy can be formulated to capitalize the image of Bandung as a culinary and shopping destination. While the functional-unique attribute component identifies the distinctive tourist attractions in Bandung, the psychological-unique component identifies the moods and atmospheres that uniquely experienced by tourists in Bandung. For the development of the tourism sector, the destination marketing organization of Bandung needs to supplement these emotional atmospheres experienced by the tourists in their marketing communication material.

This study reveals the image of Bandung more comprehensively compared to previous studies. However, as the Bandung tourism market environments are always in a dynamic state, subsequence studies using similar approach need to be conducted on a regular basis to monitor any changes that may emerge in the image of Bandung as a tourist destination.

\section{REFERENCES}

Agustiani, T. N. (2017). Analisis citra Bandung sebagai destinasi wisata belanja. (Bachelor), Politeknik Negeri Bandung, Bandung.

Assaker, G., Vinzi, V. E., \& O'Connor, P. (2011). Examining the effect of novelty seeking, satisfaction, and destination image on tourists' return pattern: A two factor, non-linear latent growth model. Tourism management, 32(4), 890-901. doi: 10.1016/j.tourman.2010.08.004

Baloglu, S. (2000). A path analytic model of visitation intention involving information sources, sociopsychological motivations, and destination image. Journal of Travel \& Tourism Marketing, 8(3), 81-9o. doi: 10.1300/Jo73vo8no3_05

Baloglu, S., \& Brinberg, D. (1997). Affective images of tourism destinations. Journal of Travel Research, 35(4), 11-15. doi: 10.1177/004728759703500402

Baloglu, S., \& Love, C. (2005). Association meeting planners' perceptions and intentions for five major US convention cities: the structured and unstructured images. Tourism management, 26(5), 743-752. doi: 10.1016/j.tourman.2004.04.001

Baloglu, S., \& Mangaloglu, M. (2001). Tourism destination images of Turkey, Egypt, Greece, and Italy as perceived by US-based tour operators and travel agents. Tourism management, 22(1), 1-9. doi: 10.1016/So261-5177(oo)ooo3o-3

Baloglu, S., \& McCleary, K. W. (1999a). A model of destination image formation. Annals of tourism research, 26(4), 868-897. doi: 10.1016/s016o-7383(99)ooo3o-4 
Baloglu, S., \& McCleary, K. W. (1999b). US international pleasure travelers' images of four Mediterranean destinations: A comparison of visitors and nonvisitors. Journal of Travel Research, 38(2), 144-152. doi: 10.1177/004728759903800207

Beerli, A. P., \& Martin, J. D. (2004). Factors influencing destination image. Annals of tourism research, 31(3), 657-681. doi: 10.1016/j.annals.2004.01.010

Chew, E. Y. T., \& Jahari, S. A. (2014). Destination image as a mediator between perceived risks and revisit intention: A case of post-disaster Japan. Tourism management, 40, 382-393. doi: 10.1016/j.tourman.2013.07.008

Choi, W. M., Chan, A., \& Wu, J. (1999). A qualitative and quantitative assessment of Hong Kong's image as a tourist destination. Tourism management, 2o(3), 361-365. doi: 10.1016/So2615177(98)oo116-2

Court, B., \& Lupton, R. A. (1997). Customer portfolio development: modeling destination adapters, inactives, and rejecters. Journal of Travel Research, 36(1), 35-43. doi: 10.1177/004728759703600106

Dolnicar, S., \& Grün, B. (2013). Validly measuring destination image in survey studies. Journal of Travel Research, 52(1), 3-14. doi: 10.1177/0047287512457267

Echtner, C. M., \& Ritchie, J. R. (1991). The meaning and measurement of the image of the destination. Journal of Tourism Studies, 2(2), 2-12. doi: 10.1177/004728759303100402

Efendi, A. (2017, 27 Maret 2017). Turis Malaysia Antusias ke Pasar Baru dan Cihampelas, Pikiran Rakyat. Retrieved from http://www.pikiran-rakyat.com/wisata/2017/03/27/turis-malaysiaantusias-ke-pasar-baru-dan-cihampelas-397288

Fakeye, P. C., \& Crompton, J. L. (1991). Image differences between prospective, first-time, and repeat visitors to the Lower Rio Grande Valley. Journal of Travel Research, 3o(2), 10-16. doi: 10.1177/004728759103000202

Hair, J. F., Black, W. C., Babin, B., \& Anderson, R. E. (2010). Multivariate data analysis (7th ed.). New Jersey: Pearson.

Hui, T. K., \& Wan, T. W. D. (2003). Singapore's image as a tourist destination. International journal of tourism research, 5(4), 305-313. doi: 10.1002/jtr.437

Khoiriana, R., \& Nurlambang, T. (2017). Brand image kota Bandung. Paper presented at the Indutrial Research Workshop and National Seminar, Bandung.

Lee, C. K., Lee, Y. K., \& Lee, B. (2005). Korea's destination image formed by the 2002 World Cup. Annals of tourism research, 27(4), 839-858. doi: 10.1016/j.annals.2004.11.006

Li, C. L., Chick, G. E., Wu, H. C., \& Yen, T. M. (2010). Examining the dimensionality of values for culturally diverse customers in parks and recreation. World Leisure Journal, 52(2), 80-93. doi: 10.1080/04419057.2010.9674633

Li, M., Cai, L. A., Lehto, X. Y., \& Huang, J. (2010). A missing link in understanding revisit intentionThe role of motivation and image. Journal of Travel \& Tourism Marketing, 27(4), 335-348. doi: 10.1080/10548408.2010.481559

Li, X., \& Stepchenkova, S. (2012). Chinese outbound tourists' destination image of America: Part I. Journal of Travel Research, 51(3), 250-266. doi: 10.1177/0047287511410349

MacKay, K. J., \& Fesenmaier, D. R. (1997). Pictorial element of destination in image formation. Annals of tourism research, 24(3), 537-565. doi: 10.1016/So16o-7383(97)0oo11-X

Mardiana, D. (Producer). (2018, 8 April 2018). 99 Tempat Wisata Baru di Bandung 100\% Terbaru, Murah \& Gratis 2018. Tempat Wisata di Bandung. Retrieved from https://tempatwisatadibandung.info/tempat-wisata-baru-di-bandung/

Pan, B., \& Li, X. R. (2011). The long tail of destination image and online marketing. Annals of tourism research, 38(1), 132-152. doi: 10.1016/j.annals.2010.06.004

Pike, S. (2002). Destination image analysis--a review of 142 papers from 1973 to 200o. Tourism management, 23(5), 541-549. doi: 10.1016/So261-5177(02)0ooo5-5 
Prayag, G. (2009). Tourists' evaluations of detination image, satisfaction, and future behavioral intentions-The case of Mauritius Journal of Travel \& Tourism Marketing, 26(8), 836-853. doi: 10.1080/10548400903358729

Qu, H., Kim, L. H., \& Im, H. H. (2011). A model of destination branding: Integrating the concepts of the branding and destination image. Tourism management, 32(3), 465-476. doi: 10.1016/j.tourman.2010.03.014

Salim, D. A. (2014). Bandung menuju kota ekonomi kreatif. Retrieved 8 April 2018 https://swa.co.id/swa/trends/management/bandung-menuju-kota-ekonomi-kreatif

San Martin, H., \& Rodríguez del Bosque, I. A. (2008). Exploring the cognitive-affective nature of destination image and the role of psychological factors in its formation. Tourism management, 29(2), 263-277. doi: 10.1016/j.tourman.2007.03.012

Selby, M., \& Morgan, N. J. (1996). Reconstruing place image: A case study of its role in destination market research. Tourism management, 17(4), 287-294. doi: 10.1016/o261-5177(96)ooo20-9

Sönmez, S. F., \& Sirakaya, E. (2002). A distorted destination image? The case of Turkey. Journal of Travel Research, 41(2), 185-196. doi: 10.1177/004728702237418

Stepchenkova, S., \& Li, X. R. (2014). Destination image: Do top-of-mind associations say it all? Annals of tourism research, 45, 46-62. doi: 10.1016/j.annals.2013.12.004

Stepchenkova, S., \& Morrison, A. M. (2008). Russia's destination image among American pleasure travelers: Revisiting Echtner and Ritchie. Tourism management, 29(3), 548-56o. doi: 10.1016/j.tourman.2007.06.003

Suciani, W. (2014). Pengaruh destination image kota Bandung sebagai daerah tujuan wisata terhadap post-visit behaviour wisatawan. (Bachelor), Universitas Pendidikan Indonesia, Bandung.

Tasci, A. D. A., Gartner, W. C., \& Tamer Cavusgil, S. (2007). Conceptualization and operationalization of destination image. Journal of Hospitality \& Tourism Research, 31(2), 194223. doi: $10.1177 / 1096348006297290$

Widianto, S. (2015, 23 November 2015). Bandung Ditetapkan Sebagai Destinasi Wisata Kuliner Indonesia, Pikiran Rakyat. Retrieved from http://www.pikiranrakyat.com/wisata/2015/11/23/350975/bandung-ditetapkan-sebagai-destinasi-wisata-kulinerindonesia. 